\title{
PENGETAHUAN ANAK USIA SEKOLAH TENTANG CUCI TANGAN YANG BENAR DI KECAMATAN MARTAPURA
}

\author{
Filia Sofiani Ikasari ${ }^{1}$, Renditya Anggana ${ }^{2}$ \\ ${ }^{1}$ Program Studi Magister Keperawatan, Fakultas Ilmu Keperawatan,Universitas Indonesia \\ ${ }^{2}$ Program Studi Magister Keperawatan, Fakultas Ilmu Keperawatan \\ E-mail:*filiasofianikasari@gmail.com
}

\begin{abstract}
Abstrak
Anak usia sekolah merupakan anak dalam rentang usia enam hingga dua belas tahun. Pada rentang usia ini anak telah menghabiskan banyak waktu di sekolah dan berisiko tertular berbagai penyakit yang berasal dari lingkungan dan teman-teman di sekolah. Salah satu upaya pencegahan penularan penyakit adalah dengan melakukan cuci tangan. Kesadaran akan pentingnya cuci tangan dimulai dari pengetahuan. Penelitian ini bertujuan untuk mengetahui gambaran pengetahuan anak usia sekolah tentang cuci tangan. Penelitian ini merupakan penelitian deskripsi sederhana pada anak kelas II, III, IV dan V di Sekolah Dasar Negeri Jawa 5 Martapura dengan jumlah sampel 393 responden. Responden didapat menggunakan teknik simple random sampling. Hasil penelitian menunjukkan bahwa tingkat pengetahuan responden yang baik sebanyak 55,7\%, pengetahuan cukup 36,1\% dan pengetahuan yang kurang sebanyak $8,2 \%$ tentang cuci tangan yang benar. Penelitian ini merekomendasikan perlunya pendidikan kesehatan yang disesuaikan dengan karakteristik anak usia sekolah dan diberikan secara berkelanjutan.
\end{abstract}

Kata Kunci: Pengetahuan; cuci tangan; anak usia sekolah

\begin{abstract}
Children's knowledge of schools about true washes in Martapura district. School-age children are children in the age range of six to twelve years. In this age range the child has spent a lot of time at school and at risk of contracting various diseases that come from the environment and friends at school. One effort to prevent transmission of disease is by washing hands. Awareness of the importance of hand washing starts with knowledge. This study aims to determine the description of the knowledge of schoolage children about hand washing. This research is a simple description research in class II, III, IV and V students at the State Elementary School 5 Jawa Martapura with a sample of 393 respondents. Respondents obtained using simple random sampling technique. The results showed that respondents' good knowledge level was 55.7\%, sufficient knowledge $36.1 \%$ and insufficient knowledge as much as $8.2 \%$ about proper hand washing. This study recommends the need for health education that suitable to the characteristics of school-age children and provided on an ongoing basis.
\end{abstract}

Keywords: knowledge; hand washin; school age children 


\section{Pendahuluan}

Anak usia sekolah adalah aset bangsa yang memiliki potensi dalam memajukan pembangunan di masa mendatang. Masa sekolah merupakan masa pembentukkan kualitas sumber daya manusia yang akan berpengaruh terhadap kualitas hidup manusia selanjutnya. Anak usia sekolah sangat peka terhadap stimulus yang diberikan sehingga pada usia ini anak mudah untuk diberikan bimbingan dan ditanamkan kebiasaan untuk berperilaku hidup bersih dan sehat (Lina, 2016).

Anak usia sekolah merupakan kelompok usia terbanyak (26\%) dari total kelompok usia yang lain di dunia (Population Reference Bureau, 2018). berdasarkan data dari organisasi pendidikan, ilmu pengetahuan dan kebudayaan dunia, mendapatkan data bahwa terdapat sekitar 64 juta anak usia sekolah dasar di seluruh dunia (UNESCO, 2019). Anak usia sekolah juga merupakan kelompok usia terbanyak di Indonesia yaitu sebanyak 25 juta jiwa $(9,75 \%)$ dari total 261,8 juta penduduk Indonesia (BPS, 2018). Anak usia sekolah adalah anak dalam rentang usia 6 hingga 12 tahun. Pada rentang usia ini anak masih perlu dibina untuk dapat mencapai perkembangan intelektual sehingga dapat memprediksi tingkat bahaya yang membuatnya berisiko terhadap berbagai masalah kesehatan. Penyakit yang diderita anakanak pada awal pertumbuhannya dapat muncul kembali pada masa usia sekolah (Rosso \& Arlianti, 2009). Apabila penyakit yang dulu pernah diderita anak muncul kembali maka anak akan kesulitan melaksanakan tugas perkembangannya yang disebabkan oleh rendahnya tingkat kesehatan anak.

Masalah kesehatan yang rentan dialami oleh anak usia sekolah diantaranya adalah penyakit menular seperti diare dan Infeksi Saluran Pernapasan Akut (ISPA) (Mamta et al,
2018). Diare adalah penyakit endemis yang berpotensi menjadi kejadian luar biasa dan dapat menyebabkan kematian. Prevalensi diare di Indonesia menurut Riskesdas Indonesia pada tahun 2018 pada penduduk Indonesia dengan kelompok usia 5-14 tahun tidak kunjung mengalami penurunan dari prevalensi diare lima tahun yang lalu yakni masih mencapai $6,2 \%$. Berbeda dengan ISPA yang prevalensinya mengalami penurunan, prevalensi ISPA mencapai $4,9 \%$ dari prevalensi sebelumnya yaitu $15,4 \%$.

Organisasi kesehatan dunia yaitu World Health Organization (WHO) menyebutkan bahwa sebanyak seratus ribu anak di Indonesia meninggal dunia yang disebabkan oleh diare setiap tahunnya (Lina, 2016). Salah satu pencegahan yang efektif terhadap penyakit diare dan ISPA adalah dengan mencuci tangan (Mamta et al, 2018). Mencuci tangan yang benar menurut Riset Kesehatan Dasar Indonesia (Riskesdas) pada tahun 2018 adalah dengan menggunakan sabun dan air mengalir yang dilakukan sebelum makan, sebelum menyiapkan makanan, setelah memegang uang, memegang binatang, setelah berkebun, setelah buang air besar setelah menceboki bayi atau anak, setelah menggunakan pestisida atau insektisida dan sebelum menyusui bayi.

$$
\text { Mencuci tangan dapat }
$$
menurunkan kejadian diare sebesar 44\% (Departemen Kesehatan Republik Indonesia, 2016) dan menurunkan kejadian ISPA hingga 50\% (World Health Organization, 2007). Sehingga mencucui tangan dapat menyebabkan penurunan angka kesakitan dan kematian, serta ketidakhadiran di sekolah di antara anak-anak (Cairncross et al, 2010). Penurunan ketidakhadiran di sekolah dapat mengarah pada peningkatan prestasi anak, yang pada akhirnya dapat memiliki implikasi 
positif untuk pembangunan bangsa (Malawi Demographic \& Health Survey, 2002). Penelitian telah mengungkapkan bahwa siswa yang sering absen atau absen untuk waktu yang lama cenderung mengalami kesulitan menguasai materi yang disajikan di kelas, membuat absensi menjadi masalah pendidikan yang penting (Malawi Demographic \& Health Survey, 2002). Oleh karena itu, mencuci tangan memiliki manfaat simultan untuk meningkatkan pendidikan dan kesehatan (WHO, 2009).

Tangan harus dicuci secara teratur terutama sebelum menyiapkan atau makan makanan, setelah berada di sekitar orang sakit, sebelum dan sesudah merawat luka, setelah membersihkan anak yang menggunakan toilet, setelah menggunakan toilet, setelah menyentuh hewan, pakan ternak, atau kotoran hewan, dan setelah membersihkan atau menyentuh sampah (Centers for Disease Control and Prevention, 2012). Menurut WHO dan Pusat Pengendalian dan Pencegahan Penyakit atau Centers for Disease Control and Prevention (CDC), cara yang tepat untuk membersihkan tangan adalah dengan menggunakan sabun dan air mengalir, kemudian gosok tangan secara bersamaan dan pastikan untuk membersihkan punggung tangan, di antara jari-jari, dan di bawah kuku. Tujuan mencuci tangan adalah untuk menghilangkan mikroorganisme sementara yang mungkin ditularkan (Behrman et al, 2000). Mencuci tangan dengan sabun dan air adalah cara terbaik untuk menghilangkan kuman (Al-Khatib et al, 2015). Mencuci tangan merupakan suatu praktik membersihkan tangan dari kuman penyebab penyakit yang merupakan bagian dari perilaku mencuci tangan. Perilaku mencuci tangan terdiri dari 3 determinan salah satunya adalah pengetahuan tentang cuci tangan. Data Riskesdas Indonesia pada tahun 2018 tentang perilaku mencuci tangan diperoleh bahwa kelompok anak usia sekolah memperoleh capaian terendah untuk perilaku mencuci tangan yaitu sebesar $43 \%$.

Perilaku mencuci tangan di Kalimantan Selatan masih kurang yakni hanya mencapai 51,7\% (Riskesdas, 2018). Salah satu kecamatan dengan jumlah penduduk terbanyak di Kalimantan Selatan adalah Kecamatan Martapura yang berada di Kabupaten Banjar yakni sebanyak 113 ribu penduduk. Kasus diare masih banyak ditemukan di Kecamatan Martapura yakni mencapai 103 ribu kasus (Dinas Kesehatan Kabupaten Banjar, 2017). Berdasarkan penelitian yang dilakukan oleh peneliti sebelumnya yaitu Joni (2012) dalam Rosyidah (2014) mengenai hubungan tingkat pengetahuan, sikap dan perilaku kebersihan siswa sekolah dasar dengan kejadian diare didapatkan ada hubungan antara tingkat pengetahuan, sikap dan perilaku siswa tentang kebersihan diri, yang menyebabkan kejadian diare semakin tinggi.

Tingginya angka kejadian diare dan masih kurangnya perilaku cuci tangan menunjukkan perlu ada perhatian yang serius terhadap fenomena ini. Pengetahuan tentang cuci tangan yang merupakan salah satu determinan dari perilaku cuci tangan pada anak usia sekolah perlu ditelaah sebagai data dasar dalam memberikan intervensi keperawatan komunitas. Pengetahuan dapat berasal dari pengalaman yang dimiliki individu ataupun informasi dari sumber lain yang lebih tahu seperti orang tua, guru, teman, berbagai literatur dan lainnya (Banun, 2016). Perawat komunitas memiliki peran sebagai edukator (Allender et al, 2014) dalam hal ini perlu mengkaji pengetahuan anak usia sekolah agar dapat memberikan 
intervensi keperawatan yang sesuai dengan anak usia sekolah yang merupakan generasi penerus bangsa. Berdasarkan fenomena tersebut peneliti tertarik untuk meneliti tingkat pengetahuan anak usia sekolah tentang cuci tangan yang benar di sekolah dasar negeri Kecamatan Martapura.

\section{Metode Penelitian}

Desain penelitian ini adalah desain deskriptif sederhana dengan pendekatan kuantitatif. Populasi dalam penelitian ini sebanyak 3039 siswa sekolah dasar negeri di Kecamatan Martapura, dan setelah digunakan rumus sampel Slovin diperoleh sampel sebanyak 393 siswa. Lokasi penelitian adalah di SD Negeri Jawa 5 martapura, terdapat sebanyak 700 siswa di lokasi tersebut, namun siswa yang memenuhi kriteria inklusi hanya sebanyak 500 siswa. Kriteria inklusi yang dimaksud adalah siswa dengan usia 8 hingga 13 tahun, dapat membaca dan menulis. Adapun teknik pengambilan sampel menggunakan teknik simple random sampling, dengan cara arisan, peneliti menuliskan nama anak pada kertas kemudian memberi penomoran pada setiap nama anak. Nomor pada nama anak kemudian dituliskan di lembaran kertas kecil dan digulung, selanjutnya gulungan kertas dimasukkan ke dalam sebuah kotak, kemudian peneliti mengambil sebanyak 393 gulungan dari 500 gulungan yang tersedia. Alat pengumpul data pada penelitian ini adalah kuesioner yang terdiri dari dua bagian kuesioner yaitu kuesioner data demografi dan pengetahuan mengenai konsep cuci tangan yang diadopsi peneliti dari penelitian sebelumnya dan terdiri dari 10 pertanyaan mengenai konsep cuci tangan. Adapun pengkategorian tingkat pengetahuan mengacu pada Arikunto (2010) yang mengkategorikan tingkat pengetahuan menjadi tingkat pengetahuan baik, cukup dan kurang berdasarkan skor yang didapat. Peneliti telah melakukan uji validitas dan uji reabilitas terhadap kuesioner untuk memastikan kuesioner yang digunakan layak dan dapat merepresentasikan hasil yang diinginkan oleh peneliti. Peneliti juga telah menginformasikan mengenai penelitian seperti tujuan, manfaat dan proses penelitian kepada para responden sebelum meminta persetujuan responden untuk berpartisipasi dalam penelitian ini. Selanjutnya peneliti meminta responden yang bersedia berpartisipasi untuk mengisi kuesioner yang telah disediakan peneliti.

$$
\text { Hasil dan pembahasan }
$$

Karakteristik Responden Berdasarkan Usia dan Jenis Kelamin Distribusi Responden Menurut Usia. Hasil penelitian mengenai distribusi responden berdasarkan usia dapat dilihat pada tabel 1 di bawah ini.

Tabel 1. Rerata Usia Anak Sekolah di Sekolah Dasar Negeri Kecamatan Martapura Tahun 2019

\begin{tabular}{lcccc}
\hline Variabel & Mean & SD & n & $\begin{array}{c}\mathbf{9 5 \%} \\
\text { CI }\end{array}$ \\
\hline Usia & 10,36 & 1,443 & 393 & $1,000-$ \\
& & & & 1,034 \\
\hline
\end{tabular}

Responden yang berpartisipasi pada penelitian ini berusia 8 hingga 13 tahun yang tersebar pada lima kelas yaitu kelas II hingga kelas VI sekolah dasar. Peneliti melibatkan responden dengan rentang usia tersebut dengan mempertimbangkan kemampuan membaca dan menulis responden agar dapat mengisi kuesioner penelitian. Hasil analisis pada tabel 1 menunjukkan bahwa responden yang berpartisipasi pada penelitian ini memiliki rerata usia 10 tahun. 
Responden pada rentang usia 8 hingga 10 tahun lebih kompetitif dalam kegiatan sekolah walau masih membutuhkan perhatian guru. Responden pada rentang usia ini akan membuat penilaian tentang perilaku mereka sendiri dan menetapkan standar untuk diri sendiri. Responden pada usia ini akan maniri dan mulai mengembangkan nilai-nilai moral. Selain itu pada rentang usia ini responden akan mampu mempertahankan minat, berpikir logis tentang masalah dan mulai memahami sebab akibat serta memahami konsep abstrak (Click dan Parker, 2009).

Berbeda dengan responden pada rentang usia 8 hingga 10 tahun, responden pada rentang usia 11 hingga 13 tahun dapat menerapkan logika dan memecahkan masalah. Selain itu, responden pada rentang usia ini dapat mempertimbangkan lebih dari satu solusi untuk memecahkan masalah. Responden pada rentang usia ini memiliki penguasaan bahasa lisan dan tulisan yang baik serta dapat menggunakan bahasa sehingga membawa pemahaman diri (Click dan Parker, 2009).

Hasil observasi peneliti selama pengambilan data, responden dengan usia yang lebih tua yakni rentang usia 11 hingga 13 tahun dapat mengisi kuesioner dengan waktu yang singkat dan lebih cepat dibandingkan dengan responden dengan usia yang lebih muda yakni rentang usia 8 hingga 10 tahun. Responden dengan usia yang lebih muda tampak selalu mengajukan pertanyaan kepada peneliti mengenai item-item pertanyaan dalam kuesioner sehingga mereka membutuhkan waktu cukup lama untuk mengisi kuesioner.

Distribusi Responden Menurut Jenis Kelamin. Hasil penelitian mengenai distribusi responden berdasarkan jenis kelamin dapat dilihat pada tabel 2 di bawah ini.
Tabel 2. Distribusi Jenis Kelamin pada Anak Usia Sekolah di Sekolah Dasar Negeri Kecamatan Martapura Tahun 2019

\section{Variabel Frekuensi Persentase}

(\%)

\section{Jenis}

\section{Kelamin}

\begin{tabular}{lcc}
\hline Laki-laki & 180 & 45,8 \\
\hline Perempuan & 213 & 54,2 \\
\hline Total & 393 & 100 \\
\hline
\end{tabular}

Hasil penelitian pada tabel 2 menunjukkan bahwa responden yang berpartisipasi pada penelitian ini didominasi oleh responden dengan jenis kelamin perempuan yakni sebanyak 213 $(54,2 \%)$ responden. Adapun responden dengan jenis kelamin laki-laki sebanyak $180(45,8 \%)$ responden. Hasil observasi peneliti selama pengambilan data, didapatkan bahwa responden dengan jenis kelamin perempuan sangat berhatihati dalam mengisi kuesioner yang diberikan oleh peneliti. Hal tersebut ditunjukkan dengan ketelitian responden perempuan dalam mengisi kuesioner sehingga waktu yang digunakan responden perempuan dalam mengisi kuesioner lebih lama dibandingkan dengan responden lakilaki. Namun, tidak semua responden laki-laki tampak cepat dalam mengisi kuesioner, beberapa responden laki-laki juga menunjukkan ketelitiannya dalam mengisi kuesioner yang diberikan peneliti.

Click dan Parker (2009) menyebutkan bahwa anak usia sekolah mengembangkan minat khusus untuk gender mereka dan membentuk kelompok dengan gender yang sama serta menghabiskan banyak energi dalam bermain permainan yang melibatkan fisik. Anak perempuan lebih cepat berkembang secara fisik daripada anak laki-laki. Anak memiliki tingkat energi yang tinggi dan memiliki 
koordinasi otot tubuh yang baik. Anak dengan usia yang lebih muda memilih teman yang berjenis kelamin sama, memiliki minat yang sama, dan berbagi nilai yang sama. Sangat sedikit pertemanan lintas gender dan bahkan beberapa anak antagonis terhadap anggota lawan jenis. Anak-anak perempuan berinteraksi dengan teman perempuan, saling menceritakan rahasia, menonton film, dan berbicara di telepon. Anak laki-laki berkumpul untuk bermain kejar-kejaran, bermain video game, berbagi hobi, atau berkompetisi dalam olahraga terorganisir.

\section{Karakteristik Pengetahuan Anak Usia Sekolah tentang Cuci Tangan yang Benar Berdasarkan Usia}

Hasil penelitian mengenai karakteristik pengetahuan responden tentang cuci tangan yang benar berdasarkan usia dapat dilihat pada tabel 3 di bawah ini.

Tabel 3. Gambaran Faktor Usia dengan Tingkat Pengetahuan tentang Cuci Tangan yang Benar pada Anak Usia Sekolah di Sekolah Dasar Negeri Kecamatan Martapuran Tahun 2019

\begin{tabular}{ccccc}
\hline Usia & \multicolumn{3}{c}{ Tingkat Pengetahuan } & Total \\
\cline { 2 - 4 } & Kurang & Cukup & Baik & \\
\hline 8 th & 6 & 24 & 16 & 46 \\
\hline 9 th & 10 & 46 & 40 & 96 \\
\hline 10 th & 7 & 22 & 19 & 48 \\
\hline 11 th & 2 & 22 & 58 & 82 \\
\hline 12 th & 7 & 27 & 83 & 117 \\
\hline 13 th & 0 & 1 & 3 & 4 \\
\hline
\end{tabular}

Hasil penelitian pada tabel 3 menunjukkan bahwa responden dengan usia yang lebih tua yaitu usia 11 hingga 13 tahun sebagian besar memiliki tingkat pengetahuan yang baik tentang cuci tangan benar dibandingkan dengan responden dengan usia yang lebih muda yaitu usia 8 hingga 10 tahun. Responden dengan usia yang lebih muda sebagian besar memiliki tingkat pengetahuan yang cukup tentang cuci tangan benar. Hasil penelitian ini sejalan dengan penelitian Lisafatur (2012) yang meneliti tentang hubungan karakteristik dan pengetahuan tentang kebersihan perorangan dengan Perilaku Hidup Bersih dan Sehat (PHBS) yang menyebutkan ada hubungan antara usia dengan PHBS, salah satunya cuci tangan yang benar. Namun hasil penelitian ini tidak sejalan dengan penelitian Kartika, Widagdo dan Sugihantono (2016) yang meneliti tentang faktor-faktor yang berhubungan dengan perilaku cuci tangan pakai sabun. Kartika, Widagdo dan Sugihantono (2016) menyebutkan bahwa tidak ada hubungan antara usia dengan perilaku cuci tangan.

Anak pada masa usia sekolah membentuk diri menjadi geng dengan tujuan utama memperoleh kemerdekaan dari orang dewasa. Setiap kelompok memiliki kosakata, kode berpakaian, aturan, dan kegiatan sendiri. Kelompok ini menyediakan sistem dukungan timbal balik dan rasa solidaritas ketika anak-anak belajar mengasah keterampilan sosial mereka. Adler dan Adler (1998) meneliti 200 anak usia sekolah dasar di komunitas. Adler dan Adler (1998) menemukan bahwa anakanak sangat sadar akan pentingnya geng dan kekuatan yang mereka berikan kepada anggota geng. Beberapa pengaruh positif, membantu anak-anak belajar perilaku sosial yang sesuai dan konsekuensi dari perilaku buruk. Anggota geng cenderung memiliki karakteristik yang serupa. 
Semakin meningkatnya usia anak maka anak akan semakin memikirkan pandangan geng atau kelompoknya terhadap dirinya sehingga anggota kelompok anak usia sekolah yang memiliki tingkat pengetahuan baik akan ditiru oleh teman sebaya dalam kelompok pertemanannya dan menjadi standar dalam berkegiatan sehari-hari, sehingga wajar apabila hasil penelitian menunjukkan bahwa responden dengan usia yang lebih tua yaitu usia 11 hingga 13 tahun sebagian besar memiliki tingkat pengetahuan yang baik tentang cuci tangan benar dibandingkan dengan responden dengan usia yang lebih muda yaitu usia 8 hingga 10 tahun.

\section{Karakteristik Pengetahuan Anak Usia Sekolah tentang Cuci Tangan yang Benar Berdasarkan Jenis Kelamin}

Hasil penelitian mengenai karakteristik pengetahuan responden tentang cuci tangan yang benar berdasarkan jenis kelamin dapat dilihat pada tabel 4 di bawah ini.

Tabel 4. Gambaran Faktor Jenis Kelamin Anak dengan Tingkat Pengetahuan tentang Cuci Tangan yang Benar pada Anak Usia Sekolah di Sekolah Dasar Negeri Kecamatan Martapuran Tahun 2019

\begin{tabular}{lcccc}
\hline \multicolumn{1}{c}{$\begin{array}{c}\text { Jenis } \\
\text { Kelamin }\end{array}$} & \multicolumn{2}{c}{ Tingkat Pengetahuan } & Tota \\
\cline { 2 - 4 } & $\begin{array}{c}\text { Kuran } \\
\mathbf{g}\end{array}$ & $\begin{array}{c}\text { Cuku } \\
\mathbf{p}\end{array}$ & $\begin{array}{c}\text { Bai } \\
\mathbf{k}\end{array}$ & \\
\hline Laki-laki & 19 & 69 & 92 & 180 \\
\hline $\begin{array}{l}\text { Perempua } \\
\text { n }\end{array}$ & 13 & 73 & 127 & 213 \\
\hline
\end{tabular}

Hasil penelitian pada tabel 4 menunjukkan bahwa responden dengan jenis kelamin perempuan sebagian besar memiliki tingkat pengetahuan yang baik tentang cuci tangan benar dibandingkan dengan responden dengan jenis kelamin laki-laki. Hasil penelitian ini sejalan dengan penelitian yang dilakukan oleh Al-Khatib, Abusara, dan Massoud (2015) yang meneliti tentang cuci tangan di antara warga Palestina. AlKhatib, Abusara, dan Massoud (2015) mendapatkan hasil bahwa sebanyak $89,6 \%$ responden perempuan melaporkan mencuci tangan sebelum makan, dibandingkan dengan responden laki-laki yang hanya sebesar $80,4 \%$ melaporkan mencuci tangan sebelum makan. Berdasarkan temuan tersebut Al-Khatib, Abusara, dan Massoud (2015) menyimpulkan bahwa responden laki-laki cenderung lebih sedikit melakukan cuci tangan dibandingkan dengan responden perempuan. Hal tersebut didukung oleh penelitian sebelumnya yang dilakukan oleh Harris Interactive (2010) yang meneliti tentang kebiasaan mencuci tangan orang Amerika. Harris Interactive (2010) menemukan bahwa sebesar $83 \%$ responden perempuan yang disurvei mengatakan bahwa mereka selalu mencuci tangan sebelum menyentuh makanan dan makan dibandingkan dengan responden laki-laki yang hanya sebesar $71 \%$ melaporkan mencuci tangan sebelum menyentuh makanan dan makan.

Hasil penelitian tersebut dapat dimaknai bahwa responden dengan jenis kelamin perempuan lebih memahami pentingnya cuci tangan dibandingkan dengan responden dengan jenis kelamin laki-laki. Hal tersebut dapat terlihat dalam bentuk praktik cuci tangan yang lebih banyak dilakukan responden perempuan dibandingkan dengan responden laki-laki. Namun hasil penelitian ini tidak sejalan dengan penelitian Kartika, Widagdo dan Sugihantono (2016) yang menyebutkan bahwa tidak ada hubungan antara jenis kelamin dengan perilaku cuci tangan. 


\section{Tingkat Pengetahuan Anak Usia Sekolah tentang Cuci Tangan yang Benar}

Hasil penelitian mengenai tingkat pengetahuan responden tentang cuci tangan yang benar dapat dilihat pada tabel 5 di bawah ini.

Tabel 5. Distribusi Pengetahuan tentang Cuci Tangan yang Benar pada Anak Usia Sekolah Sekolah Dasar Negeri Kecamatan Martapura Tahun 2019

\begin{tabular}{lcc}
\hline \multicolumn{1}{c}{ Variabel } & Frekuensi & $\begin{array}{c}\text { Persentase } \\
(\boldsymbol{\%})\end{array}$ \\
\hline $\begin{array}{l}\text { Tingkat } \\
\text { Pengetahuan }\end{array}$ & & \\
\hline Baik & 219 & 55,7 \\
\hline Cukup & 142 & 36,1 \\
\hline Kurang & 32 & 8,2 \\
\hline Total & 393 & 100 \\
\hline
\end{tabular}

Hasil penelitian pada tabel 5 menunjukkan bahwa lebih dari separuh responden yaitu sebesar $55,7 \%$ responden memiliki tingkat pengetahuan yang baik tentang cuci tangan benar, sebesar $36,1 \%$ responden memiliki tingkat pengetahuan yang cukup tentang cuci tangan benar dan sebesar $8,2 \%$ responden memiliki tingkat pengetahuan yang kurang tentang cuci tangan yang benar. Persentase yang tinggi pada tingkat pengetahuan yang baik tentang cuci tangan ini dapat disebabkan oleh karakteristik responden yang senang berinteraksi dengan teman sebayanya, seperti yang diungkapkan oleh Kartika, Widagdo dan Sugihantono (2016) yang menyebutkan bahwa ada hubungan antara dukungan teman sebaya dengan perilaku cuci tangan. Hal tersebut didukung oleh Click dan Parker (2009) yang menyebutkan bahwa anak usia sekolah sangat patuh terhadap aturan pertemanan, di mana jika anak melihat cuci tangan yang benar sebagai sebuah standar yang sering dilakukan teman sebayanya, anak akan berusaha untuk memahami cara cuci tangan yang benar untuk kemudian mengadopsinya menjadi sebuah perilaku agar dapat memenuhi standar dalam pertemanan, sehingga dapat dipahami mengapa dukungan teman sebaya berpengaruh pada pengetahuan anak usia sekolah tentang cuci tangan.

Pernyataan Click dan Parker (2009) juga didukung oleh Adler dan Adler (1998) yang menyebutkan bahwa teman sebaya dalam suatu geng dapat sangat membatasi cara yang sangat spesifik untuk berperilaku, berpakaian, atau bergaul dengan orang lain di luar kelompok. Mereka yang berada di luar kelompok dapat diejek karena mengenakan pakaian yang salah, berasal dari ras atau agama yang berbeda, atau terlalu rajin belajar. Konsekuensinya adalah bahwa kefanatikan dan rasisme menjadi bagian dari sistem nilai anak-anak serta meningkatkan kebutuhan mereka untuk menyesuaikan diri dengan standar yang mungkin bertentangan dengan nilainilai yang telah mereka dapatkan di rumah.

Persentase tingkat pengetahuan yang baik selain karena dukungan teman sebaya juga dapat disebabkan adanya peran dari guru dan orang tua yang telah mengajarkan anak mengenai pentingnya mencuci tangan (Pratiwi, 2017). Sejak dini anak telah berikan atau diajari oleh orang tua di rumah mengenai cara mencuci tangan dan manfaat dari mencuci tangan. Hal tersebut didukung oleh pernyataan Ray et al (2011) yang mengatakan bahwa tahu diartikan sebagai mengingat suatu materi yang telah didapat sebelumnya. Tahu adlah tingkat pengetahuan yang 
paling rendah, termasuk dalam pengetahuan tingkat ini yaitu mengingat kembali secara spesifik seluruh materi yang telah dipelajari, sehingga pada saat anak usia sekolah diberikan pertanyaan mengenai konsep cuci tangan, mereka akan mampu mengingat kembali apa yang pernah mereka pelajari sebelumnya baik dari guru di sekolah maupun dari orang tua di rumah.

Selain data tingkat pengetahuan yang baik, pada tabel 5 juga menunjukkan data bahwa masih ada responden yang memiliki tingkat pengetahuan kurang mengenai cuci tangan yang benar yaitu sebanyak $8,2 \%$. Terdapatnya responden dengan tingkat pengetahuan yang kurang ini dapat disebabkan oleh berbagai faktor, diantaranya guru maupun petugas kesehatan yang belum efektif dalam menyampaikan informasi mengenai cuci tangan yang benar sehingga responden kurang terpapar dan belum memahami informasi mengenai cuci tangan yang benar. Sehingga, untuk meningkatkan pengetahuan responden diperlukan bimbingan dan arahan oleh guru dan petugas kesehatan dalam hal ini perawat komunitas untuk memberikan pendidikan kesehatan yang rutin dan terus-menerus agar terjadi peningkatan pengetahuan pada responden.

\section{Memberikan pengetahuan} kepada anak usia sekolah agar anak menjadi tahu adalah dengan cara membuat anak memahami hal yang dapat menjadi masalah bagi dirinya dan orang-orang di sekitarnya. Guru dan perawat komunitas harus menyadarkan anak bahwa tidak mencuci tangan dapat menyebabkan masuknya kuman ke dalam pencernaan yang kemudian akan menyebabkan berbagai penyakit akibat tidak mencuci tangan. Apabila anak belum mengetahui dan menyadari bahwa cuci tangan itu penting maka anak tidak akan bersedia untuk menerima informasi apapun. Perubahan dari tahu ke mau harus dengan menyajikan dan menampilkan faktafakta tentang masalah tersebut (Pedoman Pembinaan PHBS Kementrian Kesehatan Republik Indonesia, 2011).

Pengetahuan merupakan sesuatu yang diketahui oleh seorang individu yang didapatkan baik secara formal serta informal (Notoatmodjo, 2007). Berdasarkan hal tersebut, tingkat pengetahuan responden yang baik dapat disebabkan oleh adanya pendidikan formal yang didapat responden di sekolah mengenai pentingnya menjaga kebersihan diri salah satunya cuci tangan. Selain itu tingkat pengetahuan yang baik ini dapat disebabkan adanya pendidikan informal yang diperoleh responden dari petugas puskesmas yang secara rutin memberikan pendidikan kesehatan dengan topik yang berbedabeda kepada responden di sekolah, salah satu topiknya adalah mengenai PHBS yang di dalamnya dibahas pentingnya untuk melakukan cuci tangan yang benar.

Tingkat pengetahuan responden dapat dipengaruhi oleh berbagai macam faktor yaitu faktor pengalaman hidup, pengaruh keluarga, guru dan orang lain yang dianggap penting. Tingkat pengetahuan yang baik dapat menambah pengetahuan responden mengenai cuci tangan yang benar. Selain itu faktor lain yang dapat menambah pengetahuan responden adalah informasi. Informasi memberikan pengaruh pada pengetahuan responden, walaupun responden memiliki tingkat pendidikan yang rendah, jika responden sering terpapar informasi maka responden akan memiliki tingkat pengetahuan yang baik (Rosyidah, 2015).

Meningkatkan pengetahuan kelompok anak usia sekolah merupakan salah satu tugas dari perawat komunitas. 
Sama seperti sistem perawatan kesehatan yang terus berkembang, praktik keperawatan komunitas berkembang untuk tetap efektif dengan klien yang dilayaninya. Seiring waktu, peran perawat komunitas telah meluas. Luasnya ini tercermin dalam deskripsi keperawatan komunitas dari American Public Health Association, Public Health Nursing Section (2012) yang menyatakan bahwa perawat komunitas mengintegrasikan keterlibatan masyarakat dan pengetahuan tentang seluruh populasi dengan pemahaman klinis dan pribadi tentang pengalaman kesehatan dan penyakit individu dan keluarga dalam populasi.

Perawat komunitas menerjemahkan dan mengartikulasikan pengalaman kesehatan dan penyakit dari beragam individu dan keluarga yang rentan dalam populasi kepada perencana kesehatan dan pembuat kebijakan, dan membantu anggota masyarakat untuk menyuarakan masalah dan aspirasi mereka. Perawat komunitas memiliki pengetahuan tentang berbagai strategi untuk intervensi, dari yang berlaku untuk seluruh populasi, untuk keluarga, dan individu. Perawat komunitas menerjemahkan pengetahuan dari ilmu kesehatan dan sosial ke individu dan kelompok populasi melalui intervensi, program, dan advokasi yang ditargetkan (Allender et al, 2014).

Perawat komunitas melakukan banyak praktik sehari-hari. Namun, pada waktu tertentu, satu peran adalah yang utama. Adapun tujuh peran utama perawat komunitas adalah penyedia layanan perawatan, pendidik, advokat, manajer, kolaborator, pemimpin, dan peneliti (Allender et al, 2014). Penelitian ini dapat menjadi data dasar bagi ilmu keperawatan khususnya keperawatan komunitas untuk mengembangkan intervensi yang sesuai dengan karakteristik anak usia sekolah untuk meningkatkan perilaku yang diawali dengan meningkatkan pengetahuan anak terlebih dahulu. Hasil penelitian ini akan menunjang peran perawat komunitas sebagai edukator bagi kelompok anak usia sekolah.

Peran pendidik atau edukator bagi perawat komunitas sangat berguna dalam mempromosikan kesehatan masyarakat untuk setidaknya dua alasan. Pertama, klien komunitas biasanya tidak sakit akut dan dapat bertindak berdasarkan informasi kesehatan. Dengan demikian, peran edukator memiliki potensi untuk menemukan penerimaan yang lebih besar dan memberikan hasil yang lebih tinggi. Kedua, peran edukator dalam keperawatan kesehatan komunitas adalah penting karena audiens yang lebih luas dapat dijangkau. Dengan penekanan pada populasi dan kelompok agregasi, upaya pendidikan keperawatan kesehatan masyarakat ditargetkan tepat untuk menjangkau banyak orang. Alihalih membatasi pengajaran pada kelompok kecil, perawat memiliki kesempatan dan mandat untuk mengembangkan program pendidikan berdasarkan kebutuhan masyarakat yang akan berdampak bagi seluruh masyarakat. Kampanye mencuci tangan yang lebih baik di antara anak-anak menyediakan model yang berguna untuk implementasi peran edukator di tingkat populasi dan menunjukkan efektivitasnya dalam menjangkau khalayak luas (Redman, 2007).

\section{Simpulan}

Kesimpulan dari penelitian ini yaitu rerata usia anak yang berpartisipasi pada penelitian ini adalah anak dengan usia 10 tahun yang terdiri dari 180 (45,8\%) anak dengan jenis kelamin laki-laki dan 213 (54,2\%) anak dengan jenis kelamin perempuan. Selain itu temuan penelitian ini menunjukkan bahwa anak dengan usia yang lebih tua 
yaitu usia 11 hingga 13 tahun sebagian besar memiliki pengetahuan yang baik sedangkan anak yang lebih muda yaitu usia 8 hingga 10 tahun sebagian besar memiliki pengetahuan yang cukup tentang cuci tangan yang benar, kemudian anak dengan jenis kelamin perempuan sebagian besar memiliki pengetahuan yang baik mengenai cuci tangan yang benar dibandingkan dengan anak dengan jenis kelamin laki-laki, terakhir, anak di sekolah dasar negeri Kecamatan Martapura memiliki tingkat pengetahuan yang baik sebanyak $55,7 \%$, pengetahuan cukup $36,1 \%$ dan pengetahuan yang kurang sebanyak $8,2 \%$ tentang cuci tangan yang benar. Hasil temuan penelitian ini merekomendasikan perlu adanya pendidikan kesehatan yang disesuaikan dengan karakteristik anak usia sekolah agar terjadi peningkatan pengetahuan terutama pada anak dengan usia yang lebih muda dan anak dengan jenis kelamin laki-laki. 


\section{Referensi}

Adler, P. A., Adler, P. (1998). Peer power: Preadolescent culture and identity. Piscataway, NJ: Rutgers University Press.

Al-Khatib, I.A., Abusara, L.W., Massoud, M.A. (2015). Hand washing among Palestinians in the west bank and Gaza strip: Attitudes and practices. Journal of Environmental Health, 77(6), 5056.

Allender, J.A., Rector, C., Warner, K.D. (2014). Community and public health nursing: Promoting the public's health. $8^{\text {th }}$ Ed. United States: Lippincott William \& Wilkins.

American Nurses Association. (2007). Public health nursing: Scope and standards of practice. Silver Spring, MD: Nursesbooks.org.

Arikunto, S. (2010). Prosedur penelitian: Suatu pendekatan praktik. Edisi ke-14. Jakarta: Rineka Cipta

Badan Penelitian dan Pengembangan Kesehatan Kementrian RI. (2019). Laporan nasional riskesdas. (2018). (2019, November 21).

Badan Pusat Statistik. (2018). Statistik Indonesia 2018. Jakarta: CV. Dharmaputra.

Badan Pusat Statistik Kabupaten Banjar. (2017). Kabupaten Banjar dalam angka : Banjar regency in figures 2017. BPS Kabupaten Banjar.

Banun, T.S. (2016). Hubungan antara pengetahuan phbs (perilaku hidup bersih dan sehat) dengan pola hidup sehat siswa di SD Negeri Tamanan Bantul. (Skripsi Sarjana Pendidikan). Program Studi Pendidikan Guru Sekolah Dasar
Jurusan Pendidikan Sekolah Dasar Fakultas Ilmu Pendidikan, Universitas Negeri Yogyakarta.

Behrman, R.E., Robert, M.K., Ann, M.A. (2000). Ilmu kesehatan anak Nelson. Volume 1. Jakarta: EGC.

Cairncross, S., Hunt, C., Boisson, S., Bostoen, K., Curtis, V., Fung, I.C., Schmidt, W.P. (2010). Water sanitation and hygiene for the prevention of diarrhea. International Journal Epidemiology, 39, 193-205.

Centers for Disease Control and Prevention. (2012). Hand washing: Clean hands save lives. (2019, November 22).

Click, P.M., Parker, J. (2009). Caring for school age children. $5^{\text {th }}$ Ed. Canada: Nelson Education, Ltd.

Harris Interactive. (2010). A survey of hand washing behaviour (prepared for the American Society for Microbiology). (2019, November 22).

Kartika, M., Widagdo, L., \& Sugihananto, A. (2016). Faktorfaktor yang berhubungan dengan perilaku cuci tangan pakai sabun pada siswa Sekolah Dasar Negeri Sambiroto 01 Kota Semarang. Jurnal Kesehatan Masyarakat, 4(5), 339-346.

Kementrian Kesehatan Republik Indonesia. (2011). Pedoman pembinaan perilaku hidup bersih dan sehat (phbs). Jakarta: Peraturan Menteri Kesehatan.

Lina, H.P. (2016). Perilaku hidup bersih dan sehat (phbs) siswa di SDN 42 Korong Gadang Kecamatan Kuranji Padang. Jurnal Promkes, 4(1), 92-103.

Lisafatur, R. (2013). Hubungan karakteristik dan pengetahuan 
tentang kebersihan perorangan dengan perilaku hidup bersih dan sehat (PHBS) pada MI Matholiul Ulum Mencu Wedung Demak, Semarang. Jurnal Ilmu Keperawatan. (2019, November 22).

Malawi Demographic \& Health Survey. (2002). Education data for decision making. (2019, November 22).

Mamta, Mamta, Manisha, Kumari, M., Thakur, M., Kaur, M., Sharma, M., et al. (2018). A study to evaluate the effectiveness of structured teaching program in terms of practice regarding hand washing techniques among school going children in selected school of Barara Ambala. The Pharm Innovation Journal, 7(5), 168170.

Notoatmodjo, S. (2007). Promosi kesehatan dan ilmu perilaku. Jakarta: Rineka Cipta.

Population Reference Bureau. (2018, October 15). 2018 world population data sheet.

Pratiwi, I.D. (2017). Pengetahuan dan perilaku cuci tangan pada anak sekolah dasar di Kota Malang. Prosiding Rapat Kerja Fakultas Ilmu Kesehatan, 67-71.

Ray, S.K., Amarchand, R., Srikanth, J., Majumdar, K.K. (2011). A study on prevalence of bacteria in the hands of children and their perception on hand washing in two schools of Bangalore and Kolkata. Indian Journal of Public Health, 55(4), 293-297.

Rosso, J.M.D., Arlianti, R. (2009). Investasi kesehatan dan gizi sekolah di Indonesia. (2019, November 22).
Rosyidah, A., N. (2014). Hubungan perilaku cuci tangan terhadap kejadian diare pada siswa di Sekolah Dasar Negeri Ciputat 02. (Skripsi Sarjana Keperawatan). Program Studi Ilmu Keperawatan, Universitas Islam Negeri Syarif Hidayatullah, Jakarta.

Rosyidah, C. (2015). Hubungan antara tingkat pengetahuan dan perilaku anak sekolah dasar mengenai pemilihan makanan jajanan dengan status gizi di SD Negeri Kudu 02 Kecamatan Baki Kabupaten Sukoharjo. (Skripsi Sarjana Gizi). Program Studi Ilmu Gizi Fakultas Ilmu Kesehatan, Universitas Muhammadiyah Surakarta. (2019, November 22).

UNESCO. (2019). Out of school children and youth. (2019, November 22).

World Health Organization (WHO). (2009). A guide to implementation of the WHO multimodal hand hygiene improvement strategy. (2019, November 22). 